\title{
Methodological aspects of forming a system of indicators to evaluate asset history of production
}

\author{
Vladimir Fedoskin*, Galina Bakulina, and Maria Pikushina \\ Ryazan State Agrotechnological University Named after P.A. Kostychev, Kostychev Str., 1, 390044 \\ Ryazan, Russian Federation
}

\begin{abstract}
An all-round increase in the rate of economic development of enterprises of the agro-industrial complex, an increase in the production of agricultural products and a decrease in its cost price directly depend on the state and development of the material and technical base of enterprises, that is, on the degree of their fixed assets and the efficiency of its use. At the same time, now there is a process of reducing available fixed assets in many agricultural enterprises of the Russian Federation, that is associated with a lack of financial resources not only for the expanded reproduction of fixed assets, but also for the reimbursement of retiring assets due to their physical wear with new ones in full. Therefore, a situation often develops in agricultural enterprises when the value of retired assets is significantly higher than the value of those received. With such a ratio of retired and received fixed assets, the existing systems of indicators cannot fully characterize the asset history. In this regard, this article presents an attempt to systematize the existing systems of indicators characterizing the asset state and history, with the introduction of additional indicators, which seem to be necessary
\end{abstract}

\section{Introduction}

The rational use and expanded reproduction of fixed assets are currently one of the decisive directions for increasing the economic efficiency of production in the agricultural sector.

This, in turn, requires an accurate and reliable assessment of the asset state and history for a certain period of time. Such an assessment can be carried out using an objective system of indicators, with the help of which it is possible to comprehensively characterize the asset history at any ratio of retired and written off due to physical and moral deterioration. The obtained assessment results will contribute to the real substantiation of management decisions on the extended reproduction of fixed assets.

\footnotetext{
*Corresponding author: fedoskin.vladimir@yandex.ru
} 


\section{Materials and methods}

Analysis of the asset history and technical condition is of great importance. For this purpose, various systems of economic indicators are proposed, including the one below [1, $2,3]$ :

- the renewal coefficient $\left(\mathrm{C}_{\mathrm{ren}}\right)$, characterizing the share of new fixed assets in their total value at the end of the year:

$$
\mathrm{C}_{\text {ren }}=\frac{\text { The value of received fixed assets }}{\text { The value of fixed assets at the end of the year }}
$$

- the fixed assets renewal rate $\left(\mathrm{R}_{\mathrm{ren}}\right)$ :

$$
\mathrm{R}_{\text {ren }}=\frac{\text { The value of fixed assets at the beginning of the year }}{\text { The value of fixed assets received for the year }}
$$

- the retirement coefficient $\left(\mathrm{C}_{\mathrm{ret}}\right)$ :

$$
\mathrm{C}_{\mathrm{ret}}=\frac{\text { The value of retired fixed assets }}{\text { The value of fixed assets at the beginning of the period }}
$$

- the increment coefficient $\left(\mathrm{C}_{\mathrm{inc}}\right)$ :

$$
\mathrm{C}_{\mathrm{inc}}=\frac{\text { The value of the incriment in fixed assets }}{\text { The value of fixed assets at the beginning of the period }}
$$

- the depreciation coefficient $\left(\mathrm{C}_{\mathrm{depr}}\right)$ :

$$
\mathrm{C}_{\text {depr }}=\frac{\text { Depreciation amount of fixed assets }}{\text { The initial value of fixed assets at the relevant date }}
$$

- the feasibility coefficient $\left(\mathrm{C}_{\mathrm{f}}\right)$ :

$$
\mathrm{C}_{\mathrm{f}}=\frac{\text { Net book value of fixed assets }}{\text { The initial value of fixed assets at the relevant date }} .
$$

The following notation should be made here. The fixed assets renewal coefficient implies the use in its calculation not of the entire amount of fixed assets introduced, but only new ones, since at present farms acquire not only new fixed assets, but the used ones as well. $\left(\mathrm{C}_{\text {ifa }}\right)$ :

In this regard, some economists [4] propose to use the coefficient of input of fixed assets

$$
\mathrm{C}_{\mathrm{ifa}}=\frac{\text { The value of fixed assets entered }}{\text { The initial value of fixed assets at the end of the year }}
$$

However, some authors identify the essence of these two coefficients [5]:

- the coefficient of renewal (input) of fixed assets. 


$$
\mathrm{C}_{\mathrm{ren}}=\frac{\text { The value of fixed assets put into operation during the year }}{\text { The value of fixed assets at the end of the year }}
$$

There are other systems of indicators for characterizing the asses state and history $[6,7$, $8,9]$, consisting of two groups:

1) indicators for characterizing the asset history,

2 ) indicators for characterizing the state of fixed assets.

Group 1:

- the input coefficient:

$$
\mathrm{C}_{\mathrm{ifa}}=\frac{\text { The value of newly received fixed assets }}{\text { The value of fixed assets at the end of the year }}
$$

- the renewal coefficient $\left(\mathrm{C}_{\mathrm{ren}}\right)$ :

$$
\mathrm{C}_{\mathrm{ren}}=\frac{\text { The value of new fixed assets }}{\text { The value of fixed assets at the end of the year }}
$$

- the retirement coefficient $\left(\mathrm{C}_{\mathrm{ret}}\right)$ :

$$
\mathrm{C}_{\mathrm{ret}}=\frac{\text { The value of retired fixed assets }}{\text { The value of fixed assets at the beginning of the period }}
$$

In addition, the following coefficients are introduced [9]:

- the disposal coefficient $\left(\mathrm{C}_{\mathrm{dis}}\right)$ :

$$
\mathrm{C}_{\mathrm{dis}}=\frac{\text { The value of disposed fixed assets }}{\text { The value of fixed assets at the beginning of the period }}
$$

However, it should be noted that there is no distinction between the concepts of "retired (written off)" and "disposed" fixed assets, as a result of which it is not possible to make a distinction between "retirement coefficient of fixed assets" and "disposal coefficient of fixed assets".

- the substitution coefficient $\left(\mathrm{C}_{\mathrm{sub}}\right)$ :

$$
\mathrm{C}_{\text {sub }}=\frac{\text { The value of depreciate d fixed assets }}{\text { The value of newly received fixed assets }}
$$

The substitution coefficient shows what part of the introduced fixed assets was directed to replace the retired ones. The rest of the fixed assets is intended to expand the fleet of machinery and equipment.

In this regard, the expansion coefficient $\left(\mathrm{C}_{\mathrm{exp}}\right)$ is calculated together with the substitution coefficient:

$\mathrm{C}_{\text {exp }}=1-\mathrm{C}_{\text {sub. }}$.

Group 2:

- the depreciation coefficient $\left(\mathrm{C}_{\mathrm{depr}}\right)$ : 


$$
\mathrm{C}_{\mathrm{depr}}=\frac{\text { Depreciation amount of fixed assets }}{\text { The initial value of fixed assets }}
$$

- the suitability coefficient $\left(\mathrm{C}_{\text {suit }}\right)$ :

$$
\mathrm{C}_{\text {suit }}=\frac{\text { Price }- \text { to }- \text { book value }}{\text { The initial value of fixed assets }}
$$

The suitability coefficient can be calculated as the difference between the unit (or $100 \%$ ) and the depreciation coefficient:

$\mathrm{C}_{\text {suit }}=1-\mathrm{C}_{\text {depr; }}$ or
$\mathrm{C}_{\text {suit }}=100-\mathrm{C}_{\text {depr. }}$.

Depreciation and suitability coefficients are calculated at the beginning and end of the analyzed period.

Regarding the substitution coefficient, it should be noted that the methodology for calculating it gives objective results only if the amount of fixed assets introduced (received) exceeds (even slightly) the amount of retired (written off) assets. Otherwise, the calculation results are almost impossible to interpret.

As an example, the following 2 calculation options can be presented.

1 st option. Suppose that the amount of retired (written off) fixed assets $\left(A_{w}\right)$ amounted to 3,000 thousand rubles, and introduced (received) $\left(\mathrm{A}_{\mathrm{r}}\right)$ were 12,000 thousand rubles.

In this case, the above method for calculating the substitution and expansion coefficients gives objective results that can have unambiguous economic interpretation:

$$
\mathrm{C}_{\text {sub }}=\frac{\text { The value of fixed assets retired as a result of depreciati on }}{\text { The value of newly received fixed assets }}=\frac{\mathrm{Aw}}{\mathrm{Ar}}=\frac{3,000}{12,000}=
$$

that is, $25 \%$ of the received (introduced) fixed assets went to replace the retired (written off).

Then the expansion coefficient will be:

$\mathrm{C}_{\text {exp }}=1-\mathrm{C}_{\text {sub }}=1-0.25=0.75$, that is $75 \%$ of the introduced fixed assets were directed to their expansion.

However, in modern conditions, the cost of retired fixed assets in most enterprises of the agro-industrial complex exceeds, as a rule, the cost of introduced ones. In this regard, the 2nd option will be considered. Assume that the amount of the retired (written off) fixed assets $\left(A_{w}\right)$ was 12,000 thousand rubles and the entered (received) ones $\left(A_{r}\right)$ were 3,000 thousand rubles.

The above calculation method makes it possible to obtain the following results:

$$
\mathrm{C}_{\text {sub }}=\frac{\text { The value of fixed assets retired as a result of depreciati on }}{\text { The value of newly received fixed assets }}=\frac{\mathrm{Aw}}{\mathrm{Ar}}=\frac{3,000}{12,000}=
$$

4.

Thus, based on the economic essence of the substitution coefficient, it should be concluded that $400 \%$ of the funds received went to replace the retired ones, which is contrary to common sense, since whatever the value of the fixed assets introduced, it is taken as $100 \%$.

In this case, the expansion coefficient will take the following value:

$\mathrm{C}_{\text {exp }}=1-\mathrm{C}_{\text {sub }}=1-4=-3$.

The conclusion suggests that $(-300 \%)$ of the funds received went to replace the retired 
ones, which contradicts the logic of the economic interpretation of this coefficient.

In our opinion, the coefficient of the degree of substitution of retired fixed assets with received ones $\left(\mathrm{C}_{\mathrm{dsub}}\right)$ should be used in the second option.

The calculation methodology will be different:

$$
\mathrm{C}_{\mathrm{dsub}}=\frac{\text { The value of received (introduce } \mathrm{d} \text { ) fixed assets }}{\text { The value of retired fixed assets }}=\frac{\mathrm{Ar}}{\mathrm{Aw}}=\frac{3,000}{12,000}=0.25
$$

The value of this coefficient will indicate that the received fixed assets were sufficient to replace only $25 \%$ of the retired ones.

Together with this coefficient, the coefficient of the shortage of introduced fixed assets to substitute the retired ones $\left(\mathrm{C}_{\text {shsub }}\right)$ should be calculated: $\mathrm{C}_{\text {shsub }}=1-\mathrm{C}_{\mathrm{dsub}}=1-0.25=$ 0.75 .

The value of this coefficient indicates that received assets were not enough to replenish $75 \%$ of the retired fixed assets.

Consequently, there can be no question of expanding fixed assets at the enterprise. That is, there is a tendency to reduce the cost of fixed assets.

The state of fixed assets is also recommended to be assessed according to such a system of well-known indicators [10]:

- the renewal coefficient $\left(\mathrm{C}_{\mathrm{ren}}\right)$ :

$\mathrm{C}_{\mathrm{ren}}=\mathrm{V}_{\mathrm{r}}: \mathrm{V}_{1} \times 100 \%$,

where $\mathrm{V}_{\mathrm{r}}$ is the value of new fixed assets received (introduced) in the reporting period;

$\mathrm{V}_{1}$ is the value of fixed assets at the end of the reporting period.

This coefficient reflects the share of new fixed assets in all fixed assets at the end of the period.

The coefficient of the growth of the value of fixed assets $\left(\mathrm{C}_{\mathrm{gr}}\right)[11]: \mathrm{C}_{\mathrm{gr}}=\frac{V_{1}}{V_{0}}$.

The coefficient of renewal intensity $\left(\mathrm{C}_{\text {rin }}\right)$ reflects the amount of retired assets per unit of newly introduced objects, that is, the number of outdated objects retired as a result of the introduction of new ones [12], or otherwise "this indicator is equal to the share of fixed assets introduced to replace disposed ones" [13]. This indicator, according to the authors, characterizes the rate of technical progress. Its increase indicates a reduction in the life of funds, the disposal of obsolete facilities.

$\mathrm{C}_{\text {rin }}=\mathrm{V}_{\text {disp }}: \mathrm{V}_{\text {int }} \times 100 \%$.

The rate of introduction $\left(\mathrm{R}_{\mathrm{int}}\right)$ shows what share in the value of fixed assets at the beginning of the period is aimed at covering the disposal of fixed assets for the period:

$\mathrm{R}_{\text {int }}=\left(\mathrm{V}_{\text {int }}-\mathrm{V}_{\text {disp }}\right): \mathrm{V}_{0} \times 100 \%$,

where $V_{\text {disp }}$ is the value of fixed assets disposed in the reporting period;

$\mathrm{V}_{0}$ is the value of fixed assets at the beginning of the period.

The retirement coefficient $\left(\mathrm{C}_{\mathrm{ret}}\right)$ characterizes the share of retired fixed assets in the total value of fixed assets at the beginning of the period:

$\mathrm{C}_{\text {ret }}=\mathrm{V}_{\text {disp }}-\mathrm{V}_{0} \times 100 \%$.

With regard to this system of indicators, the following should be noted.

The renewal intensity coefficient $\left(\mathrm{C}_{\mathrm{rin}}\right)$ according to the calculation method corresponds to the substitution coefficient in other systems.

Therefore, its calculation method also gives objective results only if the value of the fixed assets introduced exceeds the value of the retired ones.

Consider the example above.

Option 1. Let's say the retired (written off) fixed assets $\left(A_{w}\right)$ amounted to 3,000 thousand rubles and the amount introduced (received) $\left(\mathrm{A}_{\mathrm{r}}\right)$ was 12,000 thousand rubles.

$\mathrm{C}_{\text {rin }}=\mathrm{V}_{\text {disp }}: \mathrm{V}_{\text {int }} \times 100 \%=3,000: 12,000 \times 100 \%=25 \%$, that is $25 \%$ was written off for every $100 \%$ of the value of the fixed assets introduced. 
An increase in the value of this coefficient will mean an increase in the number of retired assets per unit introduced, which, according to the authors of this system, is a positive fact, since it reflects the rate of technical progress.

However, with the renewal intensity coefficient $\left(\mathrm{C}_{\text {rin }}\right)$ of 100 percent or more, this will mean that for every $100 \%$ of the value of fixed assets introduced, more than $100 \%$ has been written off. And this, as a rule, leads to a reduction in the total value of fixed assets at the enterprise, which, in turn, will not contribute to an increase in production volumes, but vice versa.

Consequently, it is doubtful to draw a conclusion about the growth rate of technical progress in this situation.

Here it is appropriate to give the 2nd option of the ratio of written off and received fixed assets. The amount of retired (written off) fixed assets $\left(\mathrm{A}_{\mathrm{w}}\right)$ was 12,000 thousand rubles and introduced (received) fixed assets $\left(\mathrm{A}_{\mathrm{r}}\right)$ amounted to 3,000 thousand rubles.

$\mathrm{C}_{\text {rin }}=\mathrm{V}_{\text {disp }}: \mathrm{V}_{\text {int }} \times 100 \%=12,000: 3,000 \times 100 \%=400 \%$, that is for every $100 \%$ of the value of the fixed assets introduced, $400 \%$ was written off.

With this trend, all assets will be disposed at the enterprise within several years.

The same can be said about the rate of introduction (Rint), showing what share in the value of fixed assets at the beginning of the period is aimed at covering the disposal of fixed assets for the period:

$\mathrm{R}_{\text {int }}=\left(\mathrm{V}_{\text {int }}-\mathrm{V}_{\text {disp }}\right): \mathrm{V}_{0} \times 100 \%=(3,000-12,000): 100,000 \times 100 \%=-9 \%$.

In our opinion, the result obtained does not have an objective economic interpretation.

\section{Results and discussion}

Based on the analysis of the above systems of indicators, the conclusion is made that each of them to one degree or another characterizes the asset history and state at the enterprise. But none of them gives a complete and objective description.

In our opinion, such a characteristic can be given by the following system of indicators of the asset history and state.

This system includes two groups of indicators:

Group 1 - indicators characterizing the asset history.

Group 2 - indicators characterizing the asset state.

\section{Indicators characterizing the asset history:}

- the receipt coefficient $\left(\mathrm{C}_{\mathrm{rec}}\right)$, characterizing the share of all received fixed assets for the year in their total value at the end of the year:

$$
\mathrm{C}_{\mathrm{rec}}=\frac{\text { The value of received fixed assets }}{\text { The value of fixed assets at the end of the year }}=\frac{\mathrm{Ar}}{\mathrm{Aey}}
$$

- the renewal coefficient $\left(\mathrm{C}_{\mathrm{ren}}\right)$, characterizing the share of new fixed assets in their total value at the end of the year:

$$
\mathrm{C}_{\mathrm{ren}}=\frac{\text { The value of received new fixed assets }}{\text { The value of fixed assets at the end of the year }}=\frac{\text { Arn }}{\text { Aey }}
$$

- the fixed assets renewal rate $\left(\mathrm{R}_{\mathrm{ren}}\right)$ :

$$
R_{\text {ren }}=\frac{\text { The value of fixed assets at the beginning of the year }}{\text { The value of fixed assets received for the year }}=\frac{\text { Aby }}{\text { Arn }}
$$


- the retirement coefficient $\left(\mathrm{C}_{\mathrm{ret}}\right)$ :

$$
\mathrm{C}_{\mathrm{ret}}=\frac{\text { The value of retired (written of) fixed assets }}{\text { The value of fixed assets at the beginning of the year }}=\frac{\mathrm{Aw}}{\text { Aby }}
$$

- the increment coefficient $\left(\mathrm{C}_{\mathrm{inc}}\right)$ :

$$
\mathrm{C}_{\mathrm{inc}}=\frac{\text { The value of the incriment in fixed assets }}{\text { The value of fixed assets at the beginning of the period }}=\frac{\text { Ainc }}{\mathrm{Abp}}
$$

- the substitution coefficient $\left(\mathrm{C}_{\mathrm{sub}}\right)$ :

$$
\mathrm{C}_{\mathrm{sub}}=\frac{\text { The value of retired (written of) fixed assets }}{\text { The value of newly received fixed assets }}=\frac{\mathrm{Aw}}{\mathrm{Ar}}
$$

The substitution coefficient shows what part of the introduced fixed assets was directed to substitute for the retired ones. The rest of the fixed assets is intended to expand the fleet of machinery and equipment.

In this regard, the expansion coefficient $\left(\mathrm{C}_{\exp }\right)$ is calculated together with the substitution coefficient:

$\mathrm{C}_{\text {exp }}=1-\mathrm{C}_{\text {sub. }}$.

Coefficients of substitution and expansion are calculated, if the value of received (introduced) fixed assets exceeds the amount of retired (written off) ones.

If the opposite picture is observed, that is, the value of retired fixed assets exceeds the amount received, then the coefficient of the degree of substitution of retired fixed assets $\left(\mathrm{C}_{\mathrm{dsub}}\right)$ with received ones should be calculated).

The method for calculating it will be as follows:

$$
\mathrm{C}_{\mathrm{dsub}}=\frac{\text { The value of received (introduce } \mathrm{d} \text { ) fixed assets }}{\text { The value of retired (written off) fixed assets }}=\frac{\mathrm{Ar}}{\mathrm{Aw}}
$$

Together with this coefficient, the coefficient of the shortage of received (introduced) fixed assets should be calculated to substitute for the retired ones $\left(\mathrm{C}_{\text {shsub }}\right)$ : $\mathrm{C}_{\text {shsub }}=1-\mathrm{C}_{\mathrm{dsub}}$.

The value of this coefficient indicates how much of the retired fixed assets is not replenished by the received ones.

In other words, the value of this coefficient shows (in fractions of a unit or as a percentage) the lack of received assets for complete substitution of the retired in simple reproduction. Expanded reproduction is out of the question here.

Consequently, there can be no question of expanding fixed assets at the enterprise. That is, there is a tendency to reduce the value of fixed assets.

\section{Indicators characterizing the asset state:}

- the depreciation coefficient $\left(\mathrm{C}_{\mathrm{dep}}\right)$ :

$$
\mathrm{C}_{\mathrm{depr}}=\frac{\text { Depreciation amount of fixed assets }}{\text { The initial value of fixed assets }}=\frac{\text { Adepr }}{\text { Aif }}
$$

- the feasibility coefficient $\left(\mathrm{C}_{\mathrm{f}}\right)$ :

$$
\mathrm{C}_{\mathrm{f}}=\frac{\text { Net book value of fixed assets }}{\text { The initial value of fixed assets }}=\frac{\text { Anet }}{\text { Ainit }}
$$


The feasibility coefficient can be calculated as the difference between "one" (or 100\%) and the depreciation coefficient:

$\mathrm{C}_{\mathrm{f}}=1-\mathrm{C}_{\mathrm{dep} \text {; or }} \mathrm{C}_{\mathrm{f}}=100-\mathrm{C}_{\mathrm{dep}}[14,15,16,17]$.

Coefficients of depreciation and feasibility are calculated at the beginning and end of the analyzed period.

On the basis of the given system of indicators, coefficients were calculated that characterize the state and asset history for three years (Table 1).

The results obtained indicate that the largest increase in fixed assets was observed in 2017 (6,138 thousand rubles), as a result of which the growth rate was $57.1 \%$.

In 2016 the increase decreased to 2,996 thousand rubles (with a growth rate of $17.7 \%$ ) and in 2019 it had a negative value (-2,972 thousand rubles).

This suggests that in 2019 the disposal of fixed assets (5,280 thousand rubles) significantly exceeded their receipt (only 2,308 thousand rubles).

In 2017-2018 the amount of fixed assets received significantly exceeded the amount of the retired ones. Therefore, the coefficients of substitution and expansion were calculated for these years.

So, in $2017,38.5 \%$ of the received fixed assets went to substitute for the retired ones and $61.5 \%$ were used to expand them.

Table 1. Asset history and state

\begin{tabular}{|c|c|c|c|}
\hline & 2017 & 2018 & 2019 \\
\hline \multicolumn{4}{|l|}{ Asset history } \\
\hline 1. Availability at the beginning of the year, thousand rubles. & 10,748 & 16,886 & 19,882 \\
\hline 2. Total revenues, thousand rubles, & 9,988 & 5,976 & 2,308 \\
\hline 3. including the new ones & 7,960 & 1,150 & 1,100 \\
\hline 4. Disposal, thousand rubles & 3,850 & 2,980 & 5,280 \\
\hline 5. End of year availability, thousand rubles & 16,886 & 19,882 & 16,910 \\
\hline 6. Annual growth, thousand rubles (line $5-$ line 1 ) & $+6,138$ & $+2,996$ & $-2,972$ \\
\hline 7. Input coefficient (line $2:$ line 5), $\%$ & 59.1 & 30.1 & 13.6 \\
\hline 8. Increment coefficient (line $6:$ line 1$) \times 100, \%$ & 57.1 & 17.7 & -14.9 \\
\hline 9. Retirement coefficient (line $4:$ line 1$) \times 100, \%$ & 35.8 & 17.6 & 26.6 \\
\hline 10. Renewal coefficient (line $3:$ line 5$) \times 100, \%$ & 47.1 & 5.8 & 6.5 \\
\hline 11. Substitution coefficient $\left(\mathrm{C}_{\text {sub }}\right)$ (line $4:$ line 2$), \%$ & 38.5 & 49.9 & - \\
\hline 12. Expansion coefficient $\left(100-C_{\text {sub }}\right), \%$ & 61.5 & 50.1 & - \\
\hline $\begin{array}{l}\text { 13. Coefficient of the degree of substitution of retired fixed } \\
\text { assets with received ones (line } 2: \text { line } 4), \% \\
\text { 14. Coefficient of the shortage of introduced fixed assets to } \\
\text { substitute the retired ones }\left(C_{\text {shsub }}\right),\left(100-K_{\text {dsub }}\right), \%\end{array}$ & - & - & $\begin{array}{l}45.1 \\
54.9\end{array}$ \\
\hline \multicolumn{4}{|l|}{ Asset state } \\
\hline 15. Depreciation at the beginning of the year, thousand rubles. & 1,449 & 2,078 & 3,295 \\
\hline 16. Depreciation at the end of the year, thousand rubles. & 2,078 & 3,295 & 2,973 \\
\hline $\begin{array}{l}\text { 17. Depreciation coefficient at the beginning of the year, (line } \\
15: \text { line } 1) \times 100, \%\end{array}$ & 13.5 & 12.3 & 16.6 \\
\hline $\begin{array}{l}\text { 18. Depreciation coefficient at the end of the year, (line } 16 \text { : } \\
\text { line } 5) \times 100, \%\end{array}$ & 12.3 & 16.6 & 17.6 \\
\hline $\begin{array}{l}\text { 19. Feasibility coefficient }\left(\mathrm{C}_{\mathrm{f}}\right) \text { : } \\
\text { a) at the beginning of the year }(100-\text { line } 17), \% \\
\text { b) at the end of the year }(100-\text { line } 18), \%\end{array}$ & $\begin{array}{l}86.5 \\
87.7\end{array}$ & $\begin{array}{l}87.7 \\
83.4\end{array}$ & $\begin{array}{l}83.4 \\
82.4\end{array}$ \\
\hline
\end{tabular}

In $2018,49.9 \%$ of the introduced fixed assets were directed to replace the retired ones, and the remaining $50.1 \%$ to expand them.

A completely opposite situation developed in 2019, since the amount of retired fixed assets exceeded the value of received ones.

In this regard, the coefficients of "the degree of substitution of retired fixed assets with 
introduced ones" and "the shortage of introduced fixed assets to substitute the retired ones" were calculated.

In 2019 , the received fixed assets were enough to replace only $45.1 \%$ of the retired ones.

\section{Conclusion}

Thus, the lack of received fixed assets for complete substitution of the retired ones amounted to $54.9 \%$.

This is confirmed by the growth rate, which has a negative value $(-14.9 \%)$, that is, there is a decrease in the total value of fixed assets.

Since the introduced (received) fixed assets are not enough even to replace the retired ones, then, naturally, there can be no talk of their expanded reproduction.

Thus, the proposed system of indicators allows obtaining an objective assessment of the asset history, which will further contribute to the development and substantiation of real management decisions to optimize the process of expanded reproduction of fixed assets.

\section{References}

1. A.I. Alekseeva, Yu.V. Vasilyev, A.V. Maleeva, L.I. Ushvitskiy, Complex economic analysis of economic activity (2013)

2. L.T. Gilyarovskaya, D.V. Lysenko, D.A. Endovitskiy, Complex economic analysis of economic activity (2011)

3. V.G. Kogdenko, Economic analysis (2013)

4. G.V. Savitskaya, Analysis of the economic activity of agro-industrial complex enterprises (2013)

5. I.N. Chuev, Complex economic analysis of financial and economic activity (2013)

6. N.V. Byshov, S.N. Borychev, G.N. Bakulina, V.V. Fedoskin, I.V. Fedoskina, M.Yu. Pikushina, Religación. revista de ciencias sociales y humanidades, 4, 18, 390 (2019)

7. G. Bakulina, V. Fedoskin, M. Pikushina, V. Kukhar, E. Kot, Journal of Circuits, Systems and Signal Processing, 14, 232 (2020)

8. E.P. Polikarpova, I.E. Mizikovskiy, Custos e Agronegocio, 14(4), 149 (2018)

9. N.V. Byshov, I.A. Uspenskiy, I.A. Yukhin, N.V. Limarenko, IOP Conference Series: Earth and Environmental Science, 422(1), 012069 (2020)

10. K. Hedderwick, Financial and economic analysis of enterprises (1996)

11. E. Helfert, Technique of financial analysis: The path to creating business value (2003)

12. A.D. Sheremet, E.V. Negashev, Methods of financial analysis of activities at commercial organizations (2016)

13. N.V. Byshov, I.A. Uspenskiy, I.A. Yukhin, N.V. Limarenko, IOP Conference Series: Earth and Environmental Science, 422(1), 012069 (2020)

14. N. Byshov, I. Bogdanchikov, A. Bachurin, D. Oleinik, A. Martyshov, A. Kacharmin, IOP Conf. Series: Earth and Environmental Science, 403, 1 (2019)

15. S.D. Polischuk, G.I. Churilov, S.N. Borychev, N.V. Byshov, A.A. Nazarova, Intern. J. of Nanotechnology, 15, 4-5, 352 (2018)

16. R.N. Ushakov, A.V. Ruchkina, V.I. Levin, O.A. Zakharova, N.A. Golovina, Intern. J. of Engin. and Tech., 7, 4.36, 929 (2018) 
17. M.Yu. Kostenko, A.A. Ruzimurodov, D.N. Byshov, A.A. Golakhov, N.N. Yakutin, IOP Conference Series: Earth and Environmental Science, 422(1), 012032 (2020) 